\title{
DESENTRALISASI FISKAL DAN OTONOMI DAERAH DI INDONESIA
}

\author{
Adissya Mega Christia*, Budi Ispriyarso \\ Program Studi Magister Ilmu Hukum, Fakultas Hukum, Universitas Diponegoro \\ adissyamega@gmail.com
}

\begin{abstract}
Fiscal decentralization cannot be separated from the implementation of regional autonomy to regulate regional finance according to their respective potential. This study analyzes the problems of legislation governing the implementation of fiscal decentralization in regional autonomy and the implementation of fiscal decentralization in regional autonomy in Indonesia. This research approach is normative juridical with qualitative analysis. The conclusion of this study is that the legislation governing fiscal decentralization and regional autonomy in Indonesia has evolved from Law Number 5 of 1975 concerning the Principles of Regional Government to Law Number 23 Year 2014 concerning Regional Government but until now there are no legislation that lex specialis regulates regarding fiscal decentralization. Fiscal decentralization plays an important role in the implementation of regional autonomy in Indonesia as a means to accelerate the creation of community welfare independently in accordance with regional potential even though there are still many obstacles.
\end{abstract}

\section{Keywords: Decentralization; Fiscal; Regional Autonomy; Indonesia.}

\begin{abstract}
ABSTRAK
Desentralisasi fiskal tidak dapat dilepaskan dari pelaksanaan otonomi daerah untuk mengatur keuangan daerah sesuai potensi masing-masing. Penelitian ini menganalisis permasalahan peraturan perundangundangan yang mengatur pelaksanaan desentralisasi fiskal dalam otonomi daerah dan pelaksanaan desentralisasi fiskal dalam otonomi daerah di Indonesia. Pendekatan penelitian ini yuridis normatif dengan analisis kualitatif. Kesimpulan penelitian ini bahwa peraturan perundang-undangan yang mengatur mengenai desentralisasi fiskal dan otonomi daerah di Indonesia mengalami perkembangan mulai dari Undang-Undang Nomor 5 Tahun 1975 tentang Pokok-Pokok Pemerintahan Daerah hingga Undang-Undang Nomor 23 Tahun 2014 tentang Pemerintahan Daerah namun sampai saat ini belum ada peraturan perundang-undangan yang secara lex specialis mengatur mengenai desentralisasi fiskal. Desentralisasi fiskal berperan penting dalam pelaksanaan otonomi daerah di Indonesia sebagai sarana mempercepat terciptanya kesejahteraan masyarakat secara mandiri sesuai dengan potensi daerah meskipun masih terdapat banyak kendala.
\end{abstract}

Kata Kunci : Desentralisasi; Fiskal; Otonomi Daerah; Indonesia.

\footnotetext{
${ }^{*}$ Corresponding Author
} 
Law Reform

Volume 15, Nomor 1, Tahun 2019
Program Studi Magister IImu Hukum

Fakultas Hukum Universitas Diponegoro

\section{A. PENDAhULUAN}

Pemberian otonomi daerah pada dasarnya merupakan upaya pemberdayaan daerah dalam rangka mengelola pembangunan di daerahnya, kreativitas, inovasi dan kemandirian diharapkan akan dimiliki oleh setiap daerah, sehingga dapat mengurangi tingkat ketergantungannya pada Pemerintah Pusat. Dan yang lebih penting adalah bahwa dengan adanya otonomi daerah, kualitas pelayanan yang dilakukan oleh pemerintah kepada masyarakatnya akan meningkat, baik pelayanan yang sifatnya langsung diberikan kepada masyarakat maupun pelayanan yang tidak langsung diberikan, seperti pembuatan fasilitasfasilitas umum dan fasilitas sosial lainnya. Dengan kata lain penyediaan barang-barang publik (public goods) dan pelayanan publik (service goods) dapat lebih terjamin (Sun'an \& Senuk, 2015).

Pemberian otonomi daerah diharapkan dapat meningkatkan efisiensi, efektivitas, dan akuntabilitas sektor publik di Indonesia. Dengan otonomi daerah, daerah dituntut untuk mencari alternatif sumber pembiayaan pembangunan tanpa mengurangi harapan masih adanya bantuan dan bagian (sharing) dari Pemerintah Pusat dan menggunakan dana publik sesuai dengan prioritas dan aspirasi mesyarakat. Dengan kondisi seperti ini, perananan investasi swasta dan perusahaan milik daerah sangat diharapkan sebagai pemacu utama pertumbuhan dan pembangunan ekonomi daerah (enginee of growth). Daerah juga diharapkan mampu menarik investor untuk mendorong pertumbuhan (Makmun, 2004). Adanya otonomi daerah maka terjadi desentralisasi yang menyangkut pengelolaan keuangan daerah, perencanaan ekonomi termasuk menyusun program-program pembangunan daerah dan perencanaan lainnya yang dilimpahkan dari pusat ke daerah (Kharisma, 2013). Konsekuensi dari pelaksanaan otonomi daerah di Indonesia adalah adanya pembagian kewenangan antara Pemerintah Pusat dengan Pemerintah Daerah (bidang moneter dan fiskal nasional yang didesentralisasikan kepada daerah) (Hadi \& Saragih, 2013).

Pelaksanaan desentralisasi fiskal dan otonomi daerah di Indonesia sebagai sebuah konsekuensi politik saat ini sudah berada pada kondisi point no return, sehingga aspek-aspek yang dikedepankan lebih bersifat penguatan kapasitas serta quality improvement. Dengan demikian, ke depannya, desentralisasi fiskal dan otonomi daerah diharapkan mampu membawa Indonesia menuju kemakmuran yang inklusif dan berkelanjutan. Segala upaya dan kerja pemerintah tersebut tentu wajib mendapatkan dukungan sepenuhnya dari segala pihak yang terkait dan berkepentingan dalam mendukung suksesnya pelaksanaan desentralisasi fiskal dan otonomi di Indonesia seutuhnya. Tanpa dukungan seluruh pihak, niscaya pemerintah sendiri tidak akan mampu melaksanakan secara optimum dan pendulum otonomi justru akan lebih sering bergerak ke arah dampak yang sifatnya negatif dan merusak. Koordinasi dan kerelaan untuk saling mendukung 
Law Reform

Volume 15, Nomor 1, Tahun 2019
Program Studi Magister IImu Hukum

Fakultas Hukum Universitas Diponegoro dari segala pihak kemudian menjadi kata kunci yang utama baik di internal Pemerintahan Pusat maupun antara Pemerintah Pusat dengan Pemerintahan Daerah (Haryanto, 2015). Semua adalah masalah kompleks dalam lingkungan politik yang tidak pasti, yang pada gilirannya menimbulkan pertanyaan apakah Otonomi Daerah benar-benar bekerja menuju desentralisasi yang efektif dalam konteks Indonesia (Seymour \& Turner, 2002).

Berdasarkan penjelasan di atas maka penulisan ini menggunakan metode yuridis normatif untuk menyampaikan ide-ide konseptual dengan mempelajari berbagai literatur yang berkaitan dengan judul. Spesifikasi dari penelitian ini adalah analisis kualitatif yaitu menuangkan analisis dari literatur ke dalam penelitian melalui kalimat-kalimat.

\section{B. PEMBAHASAN}

Desentralisasi dalam konteks harafiah adalah lawan dari kata sentralisasi yang berarti pemusatan kekuasaan. Desentralisasi merupakan sebuah alat untuk mencapai salah satu tujuan bernegara, yaitu terutama memberikan pelayanan publik yang lebih baik dan menciptakan proses pengambilan keputusan publik yang lebih demokratis (Sidik, 2002). Konsep desentralisasi terdiri atas desentralisasi politik (political decentralization), desentralisasi administrasi (administrative decentralization), dan desentralisasi fiskal (fiscal decentralization) (Sidik, 2002). Desentralisasi merupakan peralihan kewenangan dari lingkungan pusat (central government) ke lingkungan pemerintah daerah (local government) untuk mengatur dan mengurusi daerahnya berdasarkan kondisi riil yang mengitarinya (Kaloh, 2002). Desentralisasi adalah penyerahan wewenang pemerintahan oleh Pemerintah Pusat kepada daerah otonom untuk mengatur dan mengurus urusan pemerintahan dalam kerangka Negara Kesatuan Republik Indonesia (NKRI) (Kumorotomo, 2008).

Desentralisasi fiskal merupakan salah satu mekanisme transfer dana dari APBN dalam kaitan dengan kebijakan keuangan negara yaitu untuk mewujudkan ketahanan fiskal yang berkelanjutan (fiscal sustainability) dan memberikan stimulus terhadap aktivitas perekonomian masyarakat, maka dengan kebijakan desentralisasi fiskal diharapkan akan menciptakan pemerataan kemampuan keuangan antar daerah yang sepadan dengan besarnya kewenangan urusan pemerintahan yang diserahkan kepada daerah otonom (Sun'an dan Senuk 2017).

Desentralisasi fiskal merupakan konsekuensi dari pelaksanaan otonomi daerah di Indonesia. Sama seperti otonomi daerah, desentralisasi fiskal pada dasarnya memiliki tujuan untuk meningkatkan potensi daerah, dalam hal ini adalah dari segi fiskal. Undang Dasar Negara Republik Indonesia Tahun 1945 yang mengamanatkan Negara Kesatuan Republik Indonesia dibagi ke dalam provinsiprovinsi kemudian dibagi lagi ke dalam wilayah kabupaten dan kota. Setiap daerah tersebut mempunyai hak dan kewajiban untuk mengatur dan 
melaksanakan sendiri urusan pemerintahan yang menjadi kewenangannya dengan menyesuaikan kemampuan keuangan daerah yang bersangkutan.

Otonomi daerah adalah hak dan wewenang daerah untuk mengatur dan mengurus sendiri urusan pemerintahan sesuai dengan kepentingan masyarakat daerah tersebut. Pemberlakuan sistem otonomi daerah merupakan amanat yang diberikan oleh Undang-Undang Dasar Negara Republik Indonesia Tahun 1945 Amandemen Kedua tahun 2000 untuk dilaksanakan berdasarkan undangundang yang dibentuk khusus untuk mengatur pemerintahan daerah (Kurniawan, 2012). Sejarah otonomi daerah di Indonesia sudah dimulai pada zaman kemerdekaan. Sejarah ini sempat terhenti saat diterapkannya sentralisasi pemerintahan pada era orde baru. Kemudian, perjalanan desentralisasi dilanjutkan seiring dengan berkembangnya era reformasi di Indonesia. Namun, ketidaksiapan institusi dan masyarakat dalam menghadapi desentralisasi ini mengakibat kan ketidakseimbangan vertikal dan horizontal (Nurhemi \& Suryani, 2015).

Menurut Said (2008), terdapat empat perspektif yang mendasari segi positif dan empat perspektif yang mendasari segi negatif otonomi daerah. Empat perspektif yang mendasari segi positif otonomi daerah, yaitu sarana untuk 1) demokratisasi, 2) membantu meningkatkan kualitas dan efisiensi pemerintahan, 3) mendorong stabilitas dan kesatuan nasional, dan 4) memajukan pembangunan daerah. Empat perspektif yang mendasari segi negatif otonomi daerah, yaitu 1) menciptakan fragmentasi dan keterpecahbelahan yang tidak diharapkan, 2) melemahkan kualitas pemerintahan, 3) menciptakan kesenjangan antardaerah yang lebih besar, dan 4) memungkinkan terjadinya penyimbanganarah demokrasi yang lebih besar.

Pelaksanaan otonomi harus dilaksanakan sesuai dengan konsep otonomi yang dimaknai sebagai penyerahan urusan Pemerintah Pusat ke daerah, kecuali lima kekuasaan yang dipergunakan untuk kelangsungan kehidupan bangsa. Namun diluar lima kekuasaan yang dikecualikan harus diserahkan pada daerah. Dengan mempertimbangkan penyerahan urusan itu sebagai usaha untuk mengurangi beban dan tuga Pemerintah Pusat. Disamping itu juga, dalam rangka meratakan tanggung jawab. Sesuai dengan sistem demokrasi, maka tanggung jawab pemerintah dapat dipikul rata oleh seluruh masyarakat yang diikutsertakan melalui disentralisasi fungsional dan teritorial. Hal ini dapat menciptakan stabilitas pemerintahan pada umumnya (Makhfudz, 2013).

\section{Implementasi Otonomi Daerah memberi} peluang besar bagi daerah untuk meningkatkan kinerja keuangan mereka sendiri. Daerah memiliki wewenang untuk mengelola dan meningkatkan sumber daya lokal mereka sendiri (Setiaji \& Adi, 2007). Namun, pelaksanaan otonomi daerah yang seringkali dipelintir menjadi "automoney" telah menyebabkan kebutuhan yang besar bagi daerah 
untuk menyusun berbagai skema keuangan daerah guna membiayai bergesernya berbagai otoritas dari pusat ke daerah (Tjandra, 2016).

Desentralisasi fiskal sejauh ini sudah memberikan dampak positif terhadap otonomi daerah di Indonesia namun belum diatur secara khusus dalam undang-undang. Instrumeninstrumen hukum yang ada dalam mengatur desentralisasi fiskal kini berguna untuk mendorong pertumbuhan ekonomi daerah, membangun kegiatan perekonomian daerah dan menjadi landasan dalam membuat peraturan perundangundangan mengenai desentralisasi fiskal di masa yang akan datang. Kebijakan desentralisasi fiskal memberi kesempatan kepada Pemerintah Daerah agar dapat memanfaatkan potensi ekonomi daerahnya sendiri untuk menyelesaikan berbagai permasalahan. Pemerintah Daerah dapat merumuskan peraturan daerah mengenai desentralisasi fiskal di daerahnya berdasarkan halhal tersebut agar pengambilan keputusan lebih didengarkan oleh masyarakat karena sesuai dengan karakter dan potensi daerah. Karena itu, hubungan antara ketimpangan dan tuntutan otonomi kompleks dan bergantung pada karakteristik daerah (Sambanis \& Milanovic, 2014). Pemerintah Daerah juga dapat memberikan masukan kepada Pemerintah Pusat untuk pengaturan mengenai desentralisasi fiskal di tingkat yang lebih tinggi yaitu undang-undang.

Pelaksanaan desentralisasi fiskal di samping memberikan dampak positif juga memungkinkan tindak korupsi karena memberikan peluang kepada Pemerintah Daerah untuk mengelola keuntungan potensi daerahnya. Bagi para pelaku korupsi di daerah, selain APBD, anggaran yang sering menjadi target korupsi adalah anggaran pemekaran daerah (Saputra, 2012). Salah satu kasus yang baru saja terjadi adalah korupsi APBD oleh 45 orang anggota DPRD Malang terhadap dana yang digunakan untuk membangun fasilitas umum. Hal ini patut mendapat perhatian bersama dari pemerintah pusat dan masyarakat karena APBD adalah fundamental dari perekonomian daerah (Putra, 2018). Peneltian sebelumnya membahas tentang efek kebijakan desentralisasi fiskal sebagai representasi implementasi kebijakan otonomi daerah berpengaruh secara parabolik (hump-shape relation) terhadap pertumbuhan ekonomi daerah dimana pada situasi desentralisasi fiskal masih rendah berpengaruh positif terhadap pertumbuhan ekonomi, tetapi setelah mencapai titik tertinggi, pengaruh desentralisasi fiskal terhadap pertumbuhan ekonomi negatif (Sumardi. 2014. Siregar, B. 2017). Pradityo (2017) membahas pengaruh desentralisasi fiskal terhadap korupsi di tingkat pemerintah daerah (provinsi) di Indonesia. Kriteria sosial ekonomi dan demografi bersama dengan faktor-faktor politik mempengaruhi tingkat otonomi fiskal pemerintah daerah di negara Yunani. (Psycharis, 2015).

Permasalahan penelitian ini membahas bagaimana peraturan perundang-undangan mengatur pelaksanaan desentralisasi fiskal dalam 
otonomi daerah dan bagaimana pelaksanaan desentralisasi fiskal dalam otonomi daerah di Indonesia.

Otonomi daerah adalah dasar pelaksanaan otonomi daerah tertuang di dalam konstitusi yaitu Undang-Undang Dasar Negara Republik Indonesia Tahun 1945 Pasal 18, 18 A dan 18 B. Sistem otonomi daerah tertulis secara umum dalam Pasal 18 untuk diatur lebih lanjut oleh undang-undang. Pasal 18 ayat (2) menyebutkan, "Pemerintahan daerah provinsi, daerah kabupaten, dan kota mengatur dan mengurus sendiri urusan pemerintahan menurut asas otonomi dan tugas pembantuan." Selanjutnya, pada ayat (5) tertulis, "Pemerintahan daerah menjalankan otonomi seluas-luasnya kecuali urusan pemerintahan yang oleh undangundang ditentukan sebagai urusan Pemerintah Pusat." Dan ayat (6) Pasal yang sama menyatakan, "Pemerintahan daerah berhak menetapkan peraturan daerah dan peraturanperaturan lain untuk melaksanakan otonomi dan tugas pembantuan.

Kebijakan desentralisasi fiskal yang dimulai sejak tahun 2001 bertujuan untuk mendorong perekonomian daerah dan mengurangi ketimpangan pendapatan antar daerah di Indonesia. Peraturan perundang-undangan yang pertama kali mendasari desentralisasi fiskal dalam otonomi daerah adalah Undang-Undang Nomor 5 Tahun 1975 tentang Pokok-Pokok Pemerintahan Di Daerah. Pada saat itu, dari evaluasi pelaksanaannya didapatkan hasil bahwa derajat desentralisasi fiskal tinggi dan ketimpangan daerah besar. Sehingga Desentralisasi fiskal di era reformasi Indonesia pertama kali dilaksanakan berdasarkan pembaharuan peraturan perundangundangan yaitu Undang-Undang Nomor 22 Tahun 1999 tentang Otonomi Daerah dan Undang-undang Nomor 25 Tahun 1999 tentang Perimbangan Keuangan antara Pemerintah Pusat dan Pemerintah Daerah. Dalam Undang-Undang Nomor 22 Tahun 1999 dituliskan bahwa pelaksanaan otonomi daerah harus mempertimbangkan kemampuan ekonomi daerah, potensi daerah, sosial budaya, sosial politik, jumlah penduduk dan luas daerah. Undang-Undang ini juga mengatur bahwa keleluasaan yang diberikan kepada daerah harus proporsional yang diwujudkan dengan pemanfaatan sumber daya di daerah secara berkeadilan dan bertanggung jawab. Pelaksanaan otonomi daerah harus sesuai dengan spirit konstitusi dan bertujuan meningkatkan kemandirian daerah dalam kerangka Negara Kesatuan Republik Indonesia. Undang-Undang Nomor 25 Tahun 1999 memperkuat dan mendukung Undang-Undang Nomor 22 Tahun 1999 dengan menjamin ketersediaan sumber-sumber fiskal bagi Pemerintah Daerah dan mendukung penyelenggaraan pemerintahan daerah yang integral dengan pemerintahan pusat.

Pelaksanaan desentralisasi fiskal di era Reformasi secara resmi dimulai sejak 1 Januari 2001. Kebijakan desentralisasi fiskal yang dimulai sejak tahun 2001 bertujuan untuk mendorong 
perekonomian daerah dan mengurangi ketimpangan pendapatan antar daerah di Indonesia (Indah, 2011). Proses tersebut diawali dengan pengesahan Undang-Undang Nomor 22 Tahun 1999 tentang Pemerintahan Daerah serta UndangUndang Nomor 25 Tahun 1999 tentang Perimbangan Keuangan Antara Pemerintah Pusat dan Daerah. Kedua regulasi tersebut sudah mengalami beberapa kali revisi hingga yang terakhir Undang-Undang Nomor 23 Tahun 2014 tentang Pemerintahan Daerah serta UndangUndang Nomor 33 Tahun 2004 tentang Perimbangan Keuangan Antara Pemerintah Pusat dan Pemerintahan Daerah. Awalnya, pelaksanaan desentralisasi fiskal di Indonesia ditujukan untuk menciptakan aspek kemandirian di daerah. Sebagai konsekuensinya, daerah kemudian menerima pelimpahan kewenangan di segala bidang, kecuali kewenangan dalam bidang politik luar negeri, pertahanan, keamanan, yustisi, moneter dan fiskal serta keagamaan. Setelah tiga dekade Orde Baru, 1967-1998, masyarakat Indonesia sedang dalam proses transformasi penting menuju era yang lebih demokratis (Setiawan \& Hadi, 2007).

Fase kedua pelaksanaan desentralisasi fiskal dalam otonomi daerah ditandai dengan adanya reformasi dalam kebijakan keuangan negara melalui penetapan paket Undang-Undang keuangan negara yang berisi tiga peraturan di bidang keuangan negara. Pertama adalah UndangUndang Nomor 17 Tahun 2003 tentang Keuangan Negara yang menetapkan bahwa asas-asas umum yang meliputi baik asas-asas yang telah lama dikenal dalam pengelolaan keuangan negara, seperti asas tahunan, asas universalitas, asas kesatuan, dan asas spesialitas maupun asas-asas baru sebagai pencerminan best practices (penerapan kaidah-kaidah yang baik) dalam pengelolaan keuangan negara, antara lain akuntabilitas, berorientasi pada hasil, profesionalitas, proporsionalitas, keterbukaan dalam pengelolaan keuangan negara, pemeriksaan keuangan oleh badan pemeriksa yang bebas dan mandiri sekaligus dimaksudkan untuk memperkokoh landasan pelaksanaan desentralisasi dan otonomi daerah di Negara Kesatuan Republik Indonesia. Kedua, Undang-Undang Nomor 1 Tahun 2004 tentang Perbendaharaan Negara yang menyatakan bahwa dalam rangka pelaksanaan desentralisasi dan otonomi daerah, kepada daerah telah diberikan kewenangan yang luas, demikian pula dana yang diperlukan untuk menyelenggarakan kewenangan itu. Ketiga, Undang-Undang Nomor 15 Tahun 2004 tentang Pemeriksaan Pengelolaan dan Tanggung Jawab Keuangan Negara yang menyangkut pula keuangan daerah.

Dalam fase ketiga, Undang-Undang Nomor 22 Tahun 1999 digantikan oleh Undang-Undang Nomor 32 Tahun 2004 tentang Pemerintahan Daerah, kemudian digantikan lagi oleh UndangUndang Nomor 23 Tahun 2014 yang di dalamnya didapatkan definisi otonomi daerah secara jelas di dalam Pasal 1 angka 6 yaitu hak, wewenang, dan 
Law Reform

Volume 15, Nomor 1, Tahun 2019
Program Studi Magister IImu Hukum

Fakultas Hukum Universitas Diponegoro kewajiban daerah otonom untuk mengatur dan mengurus sendiri Urusan Pemerintahan dan kepentingan masyarakat setempat dalam sistem Negara Kesatuan Republik Indonesia. UndangUndang Nomor 25 Tahun 1999 digantikan oleh Undang-Undang Nomor 33 Tahun 2004 tentang Perimbangan Keuangan antara Pemerintah Pusat dan Pemerintahan Daerah. Maka dari uraian di atas, peraturan perundang-undangan mengenai desentralisasi fiskal di Indonesia mengalami perkembangan. Namun sampai saat ini belum ada peraturan perundang-undangan yang secara lex specialis mengatur mengenai desentralisasi fiskal dalam otonomi daerah.

Pelaksanaan otonomi, sebagai salah satu pilihan sistem yang dapat digunakan oleh pemerintah untuk mempercepat terciptanya kesejahteraan masyarakat. Karena otonomi adalah sebagai usaha membagi rata tanggung jawab pemerintahan pusat. Kemudian beban tanggung jawab dibagi ke pemerintahan lokal, sampai yang paling bawah (Makhfudz, 2013). Sejak diberlakukannya Undang-Undang Nomor 22 Tahun 1999 tentang Pemerintahan Daerah dan UndangUndang Nomor 25 Tahun 1999 tentang Perimbangan Keuangan antara Pemerintah Pusat dan Pemerintah Daerah yang kemudian masingmasing disempurnakan dalam Undang-Undang 23 Tahun 2014 dan Undang-Undang 33 Tahun 2004, Pemerintah Daerah berwenang untuk mengelola keuangan daerah secara mandiri. Dana perimbangan merupakan inti dalam desentralisasi fiskal. Dana Perimbangan adalah dana yang bersumber dari pendapatan APBN yang dialokasikan kepada Daerah untuk mendanai kebutuhan Daerah dalam rangka pelaksanaan Desentralisasi. Dana Perimbangan bertujuan mengurangi kesenjangan fiskal antara Pemerintah dan Pemerintahan Daerah dan antar-Pemerintah Daerah. Berdasarkan Pasal 287 Undang-Undang Nomor 23 Tahun 2014 tentang Pemerintahan Daerah Dana perimbangan terdiri atas: a) $\mathrm{DBH} ; \mathrm{b}$ ) DAU; dan c) DAK. Berdasarkan peraturan Menteri Keuangan Nomor 187/Pmk.07/2016, sejak tahun 2016 dana perimbangan diubah menjadi dana transfer umum (Dana Bagi Hasil dan Dana Alokasi Umum) serta Dana Transfer Khusus (Dana Alokasi Khusus fisik dan non-fisik) (Badrudin, 2017).

Desentralisasi fiskal di Indonesia adalah khusus untuk desentralisasi expenditure, yaitu desentralisasi fiskal yang digunakan untuk belanja daerah dan besarnya ditentukan oleh diskresi masing-masing Pemerintah Daerah. Desentralisasi fiskal di Indonesia menitikberatkan pada desentralisasi di sisi pengeluaran, sehingga pemberian kewenangan pungutan perpajakan daerah dan retribusi daerah relatif terbatas, namun kepada daerah diberikan kewenangan yang luas untuk melakukan pengeluaran sesuai prioritas dan kebutuhan daerah. Sebagian besar dana transfer ke daerah bersifat block grant (dapat digunakan secara bebas oleh daerah dan dipertanggungjawabkan sepenuhnya di level 
Law Reform

Volume 15, Nomor 1, Tahun 2019
Program Studi Magister IImu Hukum

Fakultas Hukum Universitas Diponegoro daerah, yaitu kepada DPRD) (Nurhemi \& Suryani, 2015).

Dalam melaksanakan desentralisasi fiskal, menurut prinsip money should follow functions merupakan prinsip yang harus diperhatikan dan dilaksanakan (Bahl, 2000). Artinya setiap penyerahan atau pelimpahan wewenang pemerintahan membawa konsekuensi pada anggaran yang diperlukan untuk melaksanakan kewenangan tersebut. Dalam pelaksanaan desentralisasi fiskal, diperlukan keberadaan pemerintahan pusat yang kapabel dalam melakukan pengawasan dan penegakan hukum agar prinsip money follows function dapat dilaksanakan secara konsisten dan eksplisit. Hal ini untuk menghindari terjadinya transfer sumber keuangan yang sudah dikuasai oleh daerah tetapi tidak diikuti oleh tugas desentralisasi yang menjadi tanggung jawab daerah.

Dalam tahun 2018 desentralisasi fiskal di Indonesia dilaksanakan melalui Transfer ke Daerah dan Dana Desa (TKDD). TKDD merupakan salah satu komponen Belanja Negara yang mempunyai peranan sangat penting sebagai instrumen kebijakan fiskal dalam memperkuat implementasi desentralisasi fiskal untuk mempercepat pembangunan daerah dengan tujuan utama meningkatkan kualitas layanan publik (public service delivery) dan kesejahteraan masyarakat (social welfare). Dalam struktur Belanja Negara pada APBN, TKDD terdiri dari dua bagian besar, yaitu Transfer ke Daerah (TKD) yang dialokasikan untuk daerah provinsi, kabupaten dan kota, dan Dana Desa yang diberikan kepada desa. TKDD terdiri dari 4 (empat) unsur utama, yaitu Pertama, Dana Perimbangan, terdiri dari (i) Dana Transfer Umum (DTU), yaitu jenis dana transfer yang dialokasikan untuk mendanai penyelenggaraan urusan pemerintah yang menjadi kewenangan daerah, dengan memperhatikan aspek otonomi, serta keseimbangan dan pemerataan kemampuan keuangan daerah, meliputi Dana Alokasi Umum (DAU) dan Dana Bagi Hasil (DBH); (ii) Dana Transfer Khusus (DTK), yaitu dana yang dialokasikan ke daerah untuk mendanai kegiatan yang sudah diarahkan atau ditentukan penggunaannya untuk meningkatkan layanan publik dan pencapaian prioritas nasional, terdiri dari Dana Alokasi Khusus (DAK) Fisik dan DAK Nonfisik. Kedua, Dana Insentif Daerah (DID), yang dialokasikan untuk memberikan insentif dan sekaligus sebagai instrumen untuk memacu peningkatan kinerja daerah dalam pengelolaan keuangan, penyelenggaraan pemerintahan, pembangunan, pelayanan dasar publik, serta kesejahteraan masyarakat. Ketiga, Dana Otonomi Khusus (Otsus), Dana Tambahan Infrastruktur (DTI), dan Dana Keistimewaan (Dais), yaitu jenis dana transfer yang dialokasikan khusus untuk daerah-daerah yang mendapatkan kebijakan otonomi asimetri sesuai undang-undang, yaitu Provinsi Papua, Provinsi Papua Barat dan Provinsi Aceh, serta Provinsi DI Yogyakarta. Keempat, Dana Desa, yang dialokasikan kepada desa sebagai 
Law Reform

Volume 15, Nomor 1, Tahun 2019
Program Studi Magister IImu Hukum

Fakultas Hukum Universitas Diponegoro salah satu sumber pendapatan desa dari APBN untuk mendanai pembangunan desa dan pemberdayaan masyarakat sesuai dengan undangundang mengenai desa.

Kemudian dalam tahun 2018 terdapat 5 (lima) kebijakan reformulasi DAU sebagai instrumen desentralisasi fiskal untuk pemerataan fiskal antar daerah, sebagai berikut: Pertama, pagu DAU Nasional dalam APBN ditetapkan tidak lagi bersifat final atau bersifat dinamis, artinya besaran DAU dapat berubah sesuai perubahan PDN Neto dalam APBN tahun berjalan. Hal ini dimaksudkan agar daerah mempunyai kesadaran terhadap adanya risiko penerimaan negara, sehingga menjadikan daerah lebih efisien, efektif, dan produktif dalam belanjanya, dan berhati-hati dalam pengelolaan keuangan daerah. Sebagai konsekuensinya, maka daerah harus menyiapkan strategi untuk menghadapi perubahan alokasi DAU, dengan antara lain menyisihkan sebagian dari pendapatan daerah untuk membentuk dana cadangan (buffer stock), melakukan optimalisasi Pendapatan Asli Daerah (PAD), meningkatkan efisiensi belanja APBD dengan memperhatikan prioritas daerah, serta membuat sistem kontrak pekerjaan secara fleksibel sehingga dapat dilakukan perubahan apabila terjadi perubahan anggaran. Kedua, melakukan penyempurnaan formula distribusi DAU dengan mengevaluasi bobot alokasi dasar (gaji PNSD), bobot masing-masing variabel celah fiskal, baik kebutuhan fiskal maupun kapasitas fiskal daerah, serta memperbaiki indeks pemerataan kemampuan fiskal antar daerah melalui penyesuaian ke atas DAU masing-masing daerah yang mengalami penurunan secara signifikan alokasi DAU dan penyesuaian ke bawah bagi daerah-daerah yang mengalami kenaikan DAU yang sangat tinggi. Ketiga, menyesuaikan secara proporsional pembagian pagu alokasi DAU Nasional untuk daerah provinsi dan kabupaten/ kota sesuai dengan pengalihan kewenangan urusan pemerintahan dari kabupaten/kota ke provinsi. Pada tahun 2018, porsi DAU provinsi naik menjadi sebesar $14,1 \%$ dari sebelumnya tahun 2017 sebesar 10\%, sedangkan porsi DAU kabupaten/kota turun menjadi sebesar 85,9\% dari sebelumnya tahun 2017 sebesar 90\%. Keempat, memberikan afirmasi kepada daerah kepulauan melalui kebijakan peningkatan bobot luas wilayah laut dalam variabel luas wilayah dari semula 50\% untuk kabupaten/kota dan 40\% untuk provinsi menjadi 100\%. Dengan kebijakan ini, maka alokasi DAU untuk daerah berciri kepulauan meningkat dari Rp26,72 triliun pada tahun 2017 menjadi Rp27,78 triliun. Kelima, mewajibkan kepada daerah untuk mengalokasikan sekurang-kurangnya 25\% dari Dana Transfer Umum (DAU dan DBH) setiap daerah untuk membiayai belanja infrastruktur yang langsung terkait dengan percepatan pembangunan fasilitas pelayanan publik dan perekonomian daerah sesuai ketentuan Undang-Undang Nomor 15 Tahun 2017 tentang Anggaran Pendapatan dan Belanja Negara Tahun 2018 (Kementerian Keuangan Republik Indonesia, 2018). 
Berdasarkan uraian di atas menunjukkan bahwa desentralisasi fiskal sepanjang tahun 2018 berpengaruh positif terhadap pelaksanaan otonomi daerah di Indonesi terbukti dengan semakin meningkatnya pertumbuhan ekonomi daerah. Namun tetap terdapat kendala dalam pelaksanaan desentralisasi fiskal yang meliputi:

\section{a. Pemanfaatan PAD}

Sumber-sumber pendanaan yang berasal dari Pendapatan Asli Daerah (PAD) yang selama ini belum dimanfaatkan secara optimal, terutama untuk meningkatkan kemandirian daerah. $\mathrm{Hal}$ ini, mengingat masih banyak potensi PAD, khususnya dari pajak daerah dan retribusi daerah yang belum dikelola dengan efektif dan efisien.

\section{b. Korupsi}

Desentralisasi fiskal di Indonesia lebih menghasilkan "terdesentralisasikannya" korupsi ke daerah (kabupaten/kota) (Saputra \& Mahmudi, 2012). Sesuai dengan Teori Fraud Triangle bahwa munculnya kasus-kasus korupsi APBD cenderung disebabkan oleh faktor opportunity yang didukung oleh lemahnya internal. Menurut Klitgaard et.al. (2002) bahwa korupsi mengikuti kekuasaan. Korupsi pada tingkat daerah diformulasikan yaitu corruption $=$ monopoly power+discretion accountability. Korupsi dapat terjadi jika ada monopoli kekuasaan yang dipegang oleh seseorang yang memiliki kemerdekaan bertindak atau wewenang yang control. Hal yang paling menonjol berlebihan, tanpa ada dalam faktor oportunitas ini adalah maraknya kasus-kasus tersebut karena perbuatan korupsi risikonya kecil dan sanksi hukumnya juga minimal. Filmer dan Lindauer (2001) mengatakan bahwa perilaku korupsi pada tingkat daerah dapat dilihat sebagai respons terhadap faktor opportunity.

Semakin tinggi PAD, maka semakin tinggi korupsi. Hal ini memberikan indikasi bahwa PAD rentan untuk menjadi objek korupsi di daerah. Dapat dikatakan bahwa perlunya evaluasi mengenai kebijakan desentralisasi fiskal yang memberikan kewenangan (kekuasaan) besar pada pemerintah kabupaten/kota dalam pengelolaan keuangan daerah sehingga meminimisir potensi terjadinya korupsi (Saputra \& Mahmudi, 2012).

Korupsi atas APBD untuk pembangunan fasilitas umum yaitu jembatan, yang baru saja terjadi adalah korupsi massal oleh 41 orang anggota DPRD Malang. Kewenangan yang diberikan Pemerintah Pusat untuk membangun daerahnya secara mandiri dalam hal ini melalui pembangunan fasilitas umum berupa jembatan disalah gunakan dan menjadi celah untuk korupsi secara massal. Penerapan good governance di Indonesia dalam upaya pencegahan tindak pidana korupsi (Rasul, 2009).

\section{c. Pengawasan dari Pemerintah Pusat}

Korupsi yang masih terjadi di tengah pelaksanaan otonomi daerah di antaranya dengan Pemerintah Daerah menyalahgunakan kewenagannya dalam pelaksanaan desentralisasi fiskal menunjukkan bahwa Pemerintah Pusat kurang melakukan pengawasan. Pelimpahan 
wewenang bukan berarti mengurangi dan menghentikan kewajiban Pemerintah Pusat tersebut di samping adanya laporan pertanggung jawaban dari Pemerintah Daerah.

Pemerintah Pusat harus memiliki kemampuan untuk memantau dan mengevaluasi proses desentralisasi. Proses desentralisasi fiskal yang "terkendali" dan bertahap memerlukan bimbingan Pemerintah Pusat yang kuat dalam halhal seperti penerapan sistem akuntansi keuangan yang seragam, norma pemeriksaan, keterbukaan dalam hal pinjaman, dan penentuan kapan melonggarkan pengawasan atas pengeluaran, bagaimana menyesuaikan rumus distribusi substitusi, dan bagaimana menentukan batas jumlah pinjaman. Dalam beberapa bidang, diperlukan bantuan teknis kepada Pemerintah Daerah. Hal yang mendasar perlu dilakukan perubahan adalah pengawasan dan supervisi terhadap Perda di daerah yang terkait dengan fiskal sehingga Pemerintah Daerah tidak hanya memungut sebesar-besarnya dari segi penerimaan akan tetapi tidak efisiensi dari segi pengeluaran. Hal lainnya adalah pengawasan dalam pengeluaran, dalam hal pengeluaran yang bertujuan memperbesar akses publik dan meningkatkan kesejahteraan masyarakat harus diperbesar dan diperluas sedangkan pengeluaran yang tidak urgen harus ditinjau ulang dan dihapus. Memberikan sanksi bagi Kepala Daerah yang tidak mentaati Peraturan Pemerintah Pusat baik sanksi administratif, sampai pada sanksi pidana untuk memberikan efek jera bagi kepala daerah lain yang melanggar (Herwastoeti, 2010).

d. Kurangnya Peran Serta Masyarakat Desentralisasi fiskal memberikan kewenangan kepada pemerintah daerah untuk meningkatkan pendapatan dan melakukan fungsi alokatif dalam menetapkan prioritas pembangunan daerah (Putra, 2018). Fungsi alokatif tersebut membutuhkan aspirasi dari masyarakat yang sehari-hari memnfaatkan potensi daerah agar dapat terlaksana tepat pada sasaran.Peran masyarakat dalam otonomi daerah dapat dikatakan masih minim bahkan beberpa terkesan acuh. Pemerintah Pusat maupun Pemerintah Daerah harus bekerja sama untuk memberikan sosialisasi bahwa otonomi daerah memberikan kesempatan seluas-luasnya kepada masyarakat untuk menyampaikan aspirasinya kepada Pemerintah Daerah termasuk dalam pengelolaan potensi fiskal daerah, contohnya dalam pembahasan APBD. Apabila aspirasi dari masyarakat ikut menjadi pertimbangan dalam pembahasan dan penetapan APBD, maka kebijakan yang diambil akan lebih efektif, efisien dan tepat sasaran. Keterlibatan masyarakat juga memperkuat sistem pengawasan dan transparansi sebagai salah satu prinsip good governance. Penerapan good governance dalam tata pemerintahan di daerah, prasyarat yang tidak dapat ditinggalkan adalah partisipasi masyarakat dalam kebijakan publik. Ketika pemerintah menerapkan otonomi daerah dengan prinsip desentralisasi, partisipasi masyarakat menjadi prasyarat utama. 
Law Reform

Volume 15, Nomor 1, Tahun 2019
Program Studi Magister IImu Hukum

Fakultas Hukum Universitas Diponegoro
Hal ini mencakup semua aspek pelaksanaan pembangunan di daerah mulai dari perencanaan hingga pengawasan. Partisipasi masyarakat inilah yang mendorong proses demokratisasi dapat berjalan dengan lancar. Jika dianalisa secara teoritis, teori sistem David Easton sudah mewakili gambaran pentingnya partisipasi masyarakat dalam pembuatan ataupun perubahan kebijakan. Secara sederhana Easton memaparkan bahwa proses input yang berasal dari tuntutan dan dukungan masyarakat, kemudian dikonversikan oleh lembaga pembuat kebijakan, barulah dapat melahirkan output berupa kebijakan publik yang diberlakukan kepada masyarakat (Magriasti, 2011).

\section{SIMPULAN}

Peraturan perundang-undangan yang mengatur desentralisasi fiskal dan otonomi daerah di Indonesia mengalami perkembangan. Peraturan perundang-undangan tersebut meliputi UndangUndang Dasar Negara Republik Indonesia Tahun 1945 Pasal 18, 18 A dan 18 B, Undang-Undang Nomor 5 Tahun 1975 tentang Pokok-Pokok Pemerintahan di Daerah, Undang-Undang Nomor 22 Tahun 1999 tentang Otonomi Daerah, UndangUndang Nomor 25 Tahun 1999 tentang Perimbangan Keuangan Antara Pemerintahan Pusat dan Daerah, Undang-Undang Nomor 17 Tahun 2003 tentang Keuangan Negara, UndangUndang Nomor 1 Tahun 2004 tentang Perbendaharaan Negara, Undang-Undang Nomor 15 Tahun 2004 tentang Pemeriksaan Pengelolaan dan Tanggung Jawab Keuangan Negara, UndangUndang Nomor 32 Tahun 2004 tentang Pemerintahan Daerah, Undang-Undang Nomor 33 Tahun 2004 tentang Perimbangan Keuangan Antara Pemerintahan Pusat dan Daerah dan Undang-Undang Nomor 23 Tahun 2014 tentang Pemerintahan Daerah. Namun sampai saat ini belum ada peraturan perundang-undangan yang secara lex specialis mengatur mengenai desentralisasi fiskal dalam otonomi daerah.

Desentralisasi fiskal berperan penting dalam pelaksanaan otonomi daerah di Indonesia sebab desentralisasi fiskal merupakan salah satu sarana yang dapat digunakan oleh pemerintah daerah untuk mempercepat terciptanya kesejahteraan masyarakat secara mandiri sesuai dengan potensi daerah. Namun masih terdapat kendala yaitu pemanfaatan PAD, korupsi, pengawasan dari Pemerintah Pusat dan kurangnya peran serta masyarakat.

\section{DAFTAR PUSTAKA}

\section{BUKU}

Badrudin, R. (2017). Ekonomika Otonomi Daerah. Yogyakarta: UPP STIM YKPN.

Sun'an, Muammil., \& Senuk, Abdurrahman. (2015).

Ekonomi Pembangunan Daerah. Jakarta : Mitra Wacana Media.

Putra, W. (2018). Perekonomian Indonesia. Depok: Rajawali Pers.

Putra, W. (ed). (2018). Tata Kelola Ekonomi Keuangan Daerah. Depok: Rajawali Pers. 
Law Reform

Volume 15, Nomor 1, Tahun 2019
Program Studi Magister IImu Hukum Fakultas Hukum Universitas Diponegoro
Tjandra, W. (2014). Hukum Keuangan Negara. Jakarta: Grasindo.

\section{J URNAL}

Hadi, Sofyan., \& Saragih, Tomy M. (2013). Ontologi Desentralisasi Fiskal Dalam Negara Kesatuan. Perspektif, Vol. 18, (No. 3), pp.169179.

Herwastoeti. (2010). Konsep Desentralisasi Fiskal Terhadap Otonomi Daerah. Humanity, Vol. 100, (No. 2), pp.100-108.

Kharisma, B. (2013). Desentralisasi Fiskal Dan Pertumbuhan Ekonomi: Sebelum Dan Sesudah Era Desentralisasi Fiskal Di Indonesia. Jurnal Ekonomi dan Studi Pembangunan, Vol. 14, (No. 2), pp.101-119.

Kurniawan, D. (2012). Otonomi Daerah Dan Desentralisasi Fiskal Di Indonesia. E-Jurnal Unisfat, Vol. 7, (No. 2), pp.129-144.

Magriasti, L. (2011). Arti Penting Partisipasi Masyarakat dalam Kebijakan Publik Di Daerah: Analisis dengan Teori Sistem David Easton. Jurnal Proceding Simsposium Nasional Otonomi Daerah. LAB-ANE FISIF Untirta, Vol. 1, (No. 1), pp. 252-258.

Makhfudz, M. (2013). Kontroversi Pelaksanaan Otonomi Daerah. Jurnal Hukum, Vol. 3, (No 2), pp.380-407.

Nurhemi., \& Suryani, Guruh. (2015). Dampak Otonomi Keuangan Daerah Terhadap Pertumbuhan Ekonomi di Indonesia. Buletin Ekonomi Moneter dan Perbankan, Vol. 18, (
No. 2), pp.183-206.

Rasul, S. (2009). Penerapan Good Governance di Indonesia Dalam Upaya Pencegahan Tindak Pidana Korupsi. Mimbar Hukum, Vol. 1, (No. 3), pp.538-553.

Sambanis, Nicholas., \& Milanovic, Branko. (2014). Explaining Regional Autonomy Differences in Decentralized Countries. Comparative Political Studies, Vol. 47, (No. 13), pp.18301855.

Saputra, Bambang., \& Mahmudi. (2012). Pengaruh Desentralisasi Fiskal Terhadap Pertumbuhan Ekonomi Dan Kesejahteraan Masyarakat. J AAI, Vol. 9, (No. 1), pp.96-111.

Setiaji, Wirawan., \& Adi, Priyo, Hari. (2007). Peta Kemampuan Keuangan Daerah Sesudah Otonomi Daerah: Apakah Mengalami Pergeseran ? Seminar Nasional Akuntansi $X$, Vol. 1, (No. 1), pp.1-29.

Setiawan, Bakti., \& Hadi, Sudharto P. (2007). Regional Autonomy And Local Resource Management In Indonesia. Asia Pacific Viewpoint, Vol. 48, (No. 1), pp.72-84.

Seymour, Richard., \& Turner, Sarah. (2002). Otonomi Daerah: Indonesia's Decentralisation Experiment. New Zealand J ournal of Asian Studies, Vol. 4, (No. 2), pp.33-51.

Sumardi. (2015). Determinan Efektifitas pengaruh Kebijakan Desentralisasi Fiskal Terhadap Kemampuan Keuangan Daerah serta Dampaknya Pada Ekonomi Pertumbuhan Daerah (Studi Kasus: Kabupaten/Kota di 
Jawa Tengah). Journal of Rural and Development, Vol. V,(No. 2), pp.147-165

Siregar B, Pratiwi N (2017. The Effect of Local Government Charasteristics and Financial Independence on Economic Growt and Human Development Index In Indonesia. Jurnal Manajemen Dan Kewiraushaan, Vol. 19, (No.2), pp.65-71.

Psycharis, Y. Yoi, M, (2015) Decentralization and local government fiscal autonomy: evidence from the Greek municipalities. Environment and Planning C: Government and Policy, Vol. 34, (No.2), pp.262-280.

Pradiptyo, R. Suprayitno, B. (2017) Fiscal decentralization and corruption: The facts in regional autonomy in Indonesia. Journal Advanced Research of Law and Economic, Vol. 8, (No.5), pp.1458-1468.

\section{SUMBER ONLINE}

Haryanto, Joko T. (2015). Desentralisasi Fiskal Seutuhnya. Retrieved from https://www.kemenkeu.go.id/publikasi/artikeldan-opini/desentralisasi-fiskal-seutuhnyal, diakses 22 Januari 2019.

Kementerian Keuangan Republik Indonesia. (2018). APBN Kita Kinerja dan Fakta. Retrieved from https://www.kemenkeu.go.id/media/7159/apbn -kita-edisi-februari-2018.pdf, diakses 27 Januari 2019. 